\title{
The use of wild plants as food in pre-industrial Sweden
}

\section{Ingvar Svanberg*}

Uppsala Centre for Russian and Eurasian Studies, Uppsala University, Box 514, 75120 Uppsala, Sweden

\section{Abstract}

This paper is a review of the actual gathering and use of wild edible plants in the 18th and 19th centuries, with a brief concluding discussion on the present day use of wild plants as food within Sweden. The peasants and the nomads in pre-industrial Sweden utilised very few wild plant taxa as food. Many even despised the wild fruits and green plants. Some plants and fruits were earlier mostly eaten fresh on the spot, or gathered for consumption in bread, gruel or soup. Other fruits were dried or preserved in other ways. In times of food shortages the amount of wild plants increased in the diet, but still the peasantry and nomads were often able to use fish and game to provide enough nutrients.

With access to cheap sugar in the early 20th century wild fruits (Vaccinium myrtillus L., V. vitis-idaea L., and Rubus chamaemorus L.) increased in importance, especially among urban-dwellers and within food industry. In the last few decades fungi have also become part of the urban diet. Fifty years ago working class people gathered only Cantharellus cibarius (Fr.) and occasionally Boletus edulis Bull. Nowadays more taxa are utilised within the Swedish households, and especially the easy to pick Cantharellus tubaeformis (Pers.) has become very popular recently. Harvesting fruits and mushrooms in the forests is a popular pastime for many urban people, but also a source of income for immigrants and especially foreign seasonal labour. The only traditional green wild food plant that is regularly eaten in contemporary Sweden is Urtica dioica L.

Keywords: ethnobiology, plant gathering, wild food plants, famine food

\section{Introduction}

Although several studies provide information on the historical and contemporary exploitation of wild plants and non-timber products in Sweden and neighbouring Nordic countries, very few ethnobiological analyses of the use of wild food plants exist. The ethnobotanical encyclopaedias that have been published in Denmark, Norway and Sweden of course provide lots of descriptive data on plant use, including edible plants [1-3]. An ethnobotanical study about the Faroe Islands reviews most available historical data on plant use, including traditional food plants [4]. Scattered information is also at hand from Finland and Iceland $[5,6]$. The impact of the propaganda efforts in Sweden to promote the utilisation of wild plants, lichens and mushrooms has been analysed in a few scientific studies $[7,8]$. Sweden's change from a mycophobious to a rather mycophilious nation in recent years has been discussed in a couple of reviews $[9,10]$.

Cultural diversity in Sweden (and northern Scandinavia) includes the Saami minority in the north, scattered groups

\footnotetext{
*Email: ingvar.svanberg@ucrs.uu.se

This is an Open Access digital version of the article distributed under the terms of the Creative Commons Attribution 3.0 License (creativecommons.org/licenses/by/3.0/), which permits redistribution, commercial and non-commercial, provided that the article is properly cited.
}

of Roma and other Travellers, Finnish-speakers in the centre of Sweden and neighbouring parts of Norway who are nowadays completely assimilated, as well as Finnish-speakers in the province Norrbotten (including Meänkieli-speakers). Analyses of the use of food plants among the Saami exist, including the pioneering study by ethnologist Phebe Fjellström on the use of Angelica archangelica L. [11-15]. The folk botany among the various Finnish-speakers in the Scandinavian Peninsula is very little known, although rich data exists in the archives. For the Roma there is a small study on food among the Kalderaša subgroup which also includes data on wild plants [16].

The interest in researching folk botany and use of plants in their cultural historical and social contexts has increased the last 15 to 20 years. Much data has been published recently in Sweden, almost all of them in Swedish. Especially the many ethnobiological monographs, written by the present author, have analysed empirical data given in historical sources, dialect wordlists, older travelogues and handwritten records in the folk-life archives, and discussed in detail the various uses and beliefs on plant taxa in pre-industrial Sweden (e.g. [17-19]). Very few monographic articles are available in English though [11,20-23], apart from a relatively superficial review from 1951 by the ethnologist Sigurd Erixon [24].

This review of Swedish plants traditionally used as food and snacks in earlier times will fill a gap in the international ethnobiological literature. The concept of famine food and the impact of propaganda efforts will be discussed. A brief account on the contemporary use of wild plants in food culture concludes the presentation. 


\section{Material and methods}

\section{Sweden - the cultural and ecological setting}

Contemporary Sweden covers an area of around $450300 \mathrm{~km}^{2}$ and it forms the eastern part of the Scandinavian Peninsula. It includes also the islands of Gotland and Öland in the Baltic Sea. The climate is temperate. Nearly 60 per cent of the country is covered with forests and 15 per cent is located north of the Arctic Circle. Natural vegetation varies considerably due to the various climate zones and ecological settings with mountains, forest regions, coastal areas and the agricultural landscape. Eight vegetation zones can be distinguished in Sweden and the boreal zone and its sub-zones cover the most of the country.

In the 18th century Sweden was still poor, and despite considerable efforts being made, the provision of sufficient foodstuffs for the population was far from having been reliably secured. In some parts of the country the peasantry experienced frequent crop failures, and food crises and famine lurked constantly around the corner. Agriculture remained primitive and wild plants were essential for the subsistence economy, although not for human nutrition. During the 19th century land reforms, ditching projects, modernisation of agriculture and cattle breeding, better communications through steamboats and railways, and better health care that resulted in the epidemiological transition improved the situation for the population. Sweden became industrialised rather late, and in the 1880s a large part of the population was still rural and poor. Almost 1.2 million people migrated to North America between 1851 and 1930 [25].

Although still considered to be rather linguistically homogenous, Sweden also has a cultural diversity of many groups speaking various minority languages. Traditional minorities include the indigenous Saami, divided in various dialects and groups which have a background in full or semi-nomadic life styles. Due to the long historical unification with Finland (until 1809) various Finnish-speaking groups still exist within the contemporary borders. In the year 1700 the population was only 1.4 million, and in 1900 it had reached 5.1 million. The country has remained sparsely populated, especially in the north. Contemporary Sweden has a population of almost 9.5 million inhabitants (2012) including a lot of immigrant groups that have arrived since World War II as refugees and labour. They are estimated at around 15 per cent ( 1.3 million foreign born) of the population and originate from most countries of the world [26].

Export of timber products and iron ore has always been an important part of the economy, while the agricultural sector has fallen to only 2 per cent in recent years. Most people are urban, while still in the 1870 s around 70 per cent lived in the countryside [25].

\section{Sources used for this review}

Wild plants gathered for food is a fascinating primordial bio-cultural domain. An early evidence of plant gathering from Sweden is the Roman author Tacitus who described in his "De origine et situ Germanorum" (ca. 98 A.D.) how the people who are considered to be the ancestors of the Saami gathered a kind of grass that was consumed as food. This has been interpreted to mean Rumex acetosa L., which has until very recently played an important role in Saami food culture. Although occasional data on plant use can be found in various older records of wild-plant harvesting from the 16th and 17th century, such as the reports on the ethnography of the Saami provided by clergymen in the 1670 s, the real documentation of local plant use in Sweden began with Carl Linnaeus (1707-1778). His tour to Lapland and northern Scandinavia in the summer of 1732 is sometimes regarded as the starting point of ethnobotanical investigations in Sweden [27]. Thanks to his careful observations his travelogue provides us with the necessary data on where, when and from whom the data were collected, and he himself published "Flora lapponica" (1737) in Latin, where he reports also economic aspects of the plants described [28]. This book had an immense impact and became a model for botanists all over the world, but especially the data on the economic use of various plants had been passed on into many later books, thus creating a problem for later researcher to identify data originating in Linnaeus's writings, and local data [29-31]. Linnaeus published further travelogues, and they are full of information on his observations of the use of plants for food, medicine, dyes and other technical purposes among the peasantry in mid-18th century Sweden (the ones to Lapland 1732, Dalecarlia 1734, and Öland and Gotland in 1742 are available in English translations). Some of Linnaeus's prominent pupils also travelled in Sweden and gathered observations from the peasantry about useful plants. Among the most important pupils are Pehr Kalm (1716-1779), Johan Otto Hagström (1716-1792), and Anders Tidström (1723-1779). Without Linnaeus's impact and importance as a role model for later scholars the amount of data on the folk botany in Sweden would have been very mediocre [32].

Some dialectologists, ethnographers and local historians provide interesting first-hand information gathered in the field in the 19th and early 20th century on the use of wild plants. Since plant knowledge has been rather high among educated Swedes due to the importance of botany in the secondary school curricula until early 1960s, the information given is usually reliable and often contains scientific names, besides local and normalised Swedish phytonyms [33].

Important collectors of folk botanical data with information on food plants are Georg Bergfors (1882-1975), Gustav Fridner (1891-1981), Gullik Gulliksson (1894-1983), and Erik Modin (1862-1953) [33-37]. Ethnological and folklore archives also provide useful information. Such archives are to be found in Stockholm (the Nordic Museum), Gothenburg, Lund, Umeå, Uppsala and Östersund. For instance, in 1929 the Folklife Archives (present Swedish Institute for Language and Folklore) in Uppsala distributed a questionnaire on famine food in Sweden, which contained interesting data on plants used as emergency food in the late 19th century [38]. Among unpublished data collections, Lisa Johansson (1894-1982) is especially interesting since her manuscript also includes voucher specimens of the plants used in the Vilhelmina parish in northern Sweden. Another important manuscript has been compiled from the Edsele parish in Ångermanland by Frans Bergvall (1903-1995) [39,40].

The heavy loss in traditional plant knowledge in Sweden does not make further fieldwork especially appealing. On the other hand, the archives are still full of data which has not been analysed. The use and importance of wild plants among recent immigrants in Sweden is however worth field studies, for instance among Anatolian Turks, Chinese and Thais.

\section{The impact of propaganda efforts}

Food propaganda in Sweden, published as pamphlets, cookbooks, instructions, educational efforts, laws and as 
newspaper articles, is a common source for the contemporary use of many plants (fruits, mushrooms, etc.). Ever since the Age of Enlightenment, men (and a few women) of science have sought possible natural products worth exploiting on a large scale in order to improve the nutritional status of the population and of course the country's economy. The efforts have had two main goals: to benefit the national economy (by using local products or substituting valuable resources with others, for instance bark of Pinus sylvestris L. with lichens and mushrooms), and to improve the general health of the public. Luxurious imported products could be substituted with native wild plants. For instance, in 1746 the authorities published a list of 45 plant taxa, mostly native species that could be used as a substitute for tea. Imported tea was consumed by the upper classes in the early 18 th century [41].

Carl Linnaeus particularly emphasised the use of wild plants as food resources and flour substitutes. Not content with just conducting inventories of folk knowledge of useful plants, he and his contemporaries compiled lists of plants (such as his "Ceres noverca arctorum" 1733, "Plantae esculenta patriae" 1752, "De pane diaetetico" 1757, "Macellum olitorium” 1760 and a memorial in Swedish in 1757), known to be used elsewhere $[42,43]$. Another man dedicated to investigating wild plants that could be used for food was the botanist and priest Petrus Holmberger (1745-1807) [32]. The question of using wild plants as substitutes was very much in vogue among learned men in the late 18 th century. Many booklets, including several dissertations, on the issue were published from the 18th century until the early 20 th century $[7,42,44]$.

Ever since the 18th century the authorities have propagandised in different ways for new food among the peasantry with the goal of improving agriculture and diet. This propaganda intensified in conjunction with famine years and during recessions. In the pre-industrial period very few new food items were accepted or only slowly became part of diet of the common people. The intensive, almost 150 -year-long propaganda effort to introduce lichens [especially Cetraria islandica (L.) Ach.] failed completely, and mushrooms did not became generally accepted until the 1930s and 1940s. It was among the urban population that finally wild mushrooms as a food item were accepted. Many other food plants were discussed as well [7-9].

In the early 20th century, especially during the two World Wars and the period in between, many efforts were made to increase the interest for wild plants as food $[45,46]$. New media like radio probably had some impact. The increasing interest in fruits was due to the access to sugar, while modern recipes provided by cookbooks, weekly magazines, newspapers and school-instructions probably also had an impact. Cordial, jam, marmalade, gelatine desserts, biscuits and confectionary are modern products that could be made with wild berries. The interest in hips of Rosa sp. (rich in vitamin C), which was popular in the early 20th century, was a result of such educational efforts. Rose hip soup is still popular although the main ingredient is mostly bought dried in grocery stores. Also the fruits of Sorbus aucuparia L. became popular as foodstuff used for various products. It is still used as a jam served with game $[47,48]$.

Books, newspapers, magazines, radio and TV-programs still show how various wild plants can be used in the household. The right of public access to the wilderness (allemansrätten) that allows everyone to roam freely also on private land and to pick berries, mushrooms and wildflowers, is crucial for understanding the general interest for using these resources.
Also the availability for the urban people through bicycles and later cars has been of importance for the general use of wild fruits and mushrooms in the 20th century [47,49].

The impact of the propaganda was probably small before Sweden became industrialised and urbanised, although the population, including the peasantry, as in most Lutheran countries had, due to the 1686 church law, a high literacy rate (almost 100 per cent) already in the 18th century and read almanacs and newspapers. Clergymen also played an important role in instructing the common people in health care, agricultural improvements and gardening. However, when researching historical sources we must consider that the data can be influenced by these propaganda efforts rather than reflecting folk knowledge. Also the records in the folklore archives are sometimes influenced by these texts and careful source criticism is therefore necessary. For instance, local plant names seem to have been completely replaced by book-names since World War II. Ghost data must be dismissed and the impact of written data must be discussed in every ethnobotanical study using historical information. Contextual data on when, where and by whom a specific plant was used must be at hand. Icelandic lichen has for instance never been used as substitute food stuff in Sweden (or any European country outside Iceland), despite this often being said in many historical reviews $[7,31,50]$.

\section{Results}

The traditional uses of more than 100 taxa as food, spices as well as for beverages have been recorded. They are presented (with a couple of exceptions) according to the categories given by Turner et al. [51]. Some further species were used as tobacco substitutes or for flavouring tobacco. Many edible plants were used only by poor people or in connection with poor harvests and famine years. There seems to be a difference in use between the 18th and 19th centuries. Notwithstanding a wide range of efforts, the provision of sufficient foodstuffs for the population was far from having been reliably secured in the 18th century Sweden. The peasants were poorer and relied much more on subsistence economy in that century. Various green plants, used in soup and stews by the peasantry, are mentioned from the 18th century. Food crises due to crop failures were still common. The last severe starvation took place in 1772-1773 with high mortality rates $[44,52]$.

During the 19th century rural people usually despised fruits and they were only eaten locally and usually on the spot among people living in the forests or in the northern mountain areas, or by children. Fruits were not worth harvesting due to their low energy content. Only a few green plants are mentioned in the sources, mostly eaten by the rural poor. Some plants were eaten for magical purposes by the peasantry. For instance, to eat the first flowers of Hepatica nobilis Schreb. and Anemosa nemorosa L. in springtime was seen as bringing luck, protecting against snake bites or being prophylactic in general [53].

Social differences in using wild plants existed. In the 18th and early 19th centuries the upper classes, living in cities, castles and mansions, had activity fields and consumption patterns influenced by French and German culture. Therefore, there was a market for products that was not used among the peasantry. Linnaeus observed for instance young peasant women selling Gyromitra esculenta (Pers. ex. Pers.) Fr. in Småland in 1741. Still in the 19th century the peasantry gathered the species in 
the same area for selling to the cities. Sugar was expensive and the peasantry could only occasionally make sweet cakes and desserts before industrialisation. However, at the mansions it was possible, and therefore there was a small market for wild fruits such as Fragaria vesca L., Prunus avium L., Rubus arctica L. and Rubus plicatus Weihe \& Nees [3].

In southern Sweden grain production was predominant among the peasants, and they were also more reluctant to use wild plants as food. In the north the peasantry and the Saami were more dependent on gathering activities and a combination of animal husbandry, hunting, fishing and to some extent gathering of plant products. Fruits were more used among these categories. The rural poor were of course more active in gathering activities than the farmers. In the 20th century city-dwellers were eager to accept new food items, including wild mushrooms. For the post-World War II era it also seems that the working class preferred wild fruits, while the middle class has been interested in mushrooms [50].

\section{Root vegetables (roots, corms, tubers and rhizomes)}

Underground parts (roots, rhizomes, bulbs) have been recorded for several taxa. In the northern parts of Sweden the rhizomes of Calla palustris L. were widely used for making bread in the 18th and early 19th centuries. Rhizomes of Menyanthes trifoliata L. and Nuphar lutea (L.) Sm. were occasionally used as famine food. As elsewhere in Europe the bittersweet rhizomes of Polypodium vulgare L. have been eaten, especially by children. They were also recommended for their medicinal qualities (purgative) and therefore gathered and sold to the pharmacies. Occasionally, children today still gather and eat these rhizomes. The Finns in the northern and central parts of Sweden used the rhizomes of Bistorta vipipara (L.) Gray ground into flour when baking unleavened bread in the 18th century. Rhizomes of Elytrigia repens (L.) Desv. ex Nevski have been used as famine food in some parts of Sweden $[3,44]$.

The use of the edible nodules attached to rhizomes of Equisetum arvense L., known to be eaten in Norway, Iceland and the Faroe Islands, is only documented from Ångermanland and the Finnish-speaking areas of Värmland and was probably an old habit that survived among children [54]. Root tubers of Filipendula vulgaris Moench were readily eaten by free-roaming hogs, but in some parts of western Sweden poor people in the 19th century gathered them and used them to sweeten porridge [3].

\section{Edible greens (leaves, stems, shoots)}

Very few green vegetables harvested in the wild have been used by the peasantry in Sweden. The Saami utilised Angelica archangelica L., Rumex acetosa L., Cicerbita alpina (L.) Wallr., Oxyria digyna L. and occasionally also the leaves of Epilobium angustifolium L. and Alchemilla vulgaris L., mainly for mixing it with reindeer milk [11-13,17,55].

Also the Swedish settlers in northern Sweden used especially Cicerbita alpina for food. Spring shoots of Urtica dioica L. have been generally eaten in Sweden, known already in 18 th century. It was very commonly eaten, according to Linnaeus. Still many people gather it for making soup. It is also available in some weekly markets. Rumex acetosa L., earlier widely gathered, was mainly used by children during the 20th century. However, it has recently become part of haute cuisine, although usually replaced by the cultivated Rumex rugosus Campd. Immigrants from Anatolia still gather wild R. acetosa
L. for food. Strobils of Equisetum arvense L. were earlier eaten in some parts of Sweden [3,56].

Leaves, normally used as animal fodder, were, in times of food shortages, used as additives in bread. There is evidence of using leaves of Salix caprea L. and Tilia cordata L. Buds of Tilia cordata and Corylus avellana L. were also used in flour for bread according to several sources. Fresh shoots of Pinus sylvestris was sometimes also utilised in bread [56].

Many other plants were earlier gathered for stews and soup, and their importance increased in famine years, for instance Aegopodium podagraria L., Allium oleraceum L., Allium schoenoprasum L., Allium scorodprasum L., Anchusa officinalis L., Anthriscus sylvestris (L.) Hoffm., Aster tripolium L., Barbarea vulgaris R. Br. (widely cultivated in the 18th century), Circium palustre (L.) Scop., Cirsium helenioides Hill, Crambe maritima L., Galeopsis bifida (Boenn.) Fries, Campanula latifolia L., Hypochoeris maculata L., Lamium album L., Lamium purpureum L., Ranunculus ficaria L., Ribes uva-crispa L. (leaves) and Sinapis arvensis L. Most of these data were recorded in the 18th century. Some plants, usually considered as fodder, have been eaten in times of food crisis, such as Epilobium angustifolium L. among the settlers in the north [3,24,35-38,40,56].

The itinerant Kalderaša Roma gathered in the late 19th and early 20th century Chenopodium album and Taraxacum and used these plants in salads and soup [16]. The former taxon is also gathered by Greek immigrants in Sweden.

The only Pteridophyta eaten today, besides the occasional use of polypody rhizomes among children, are the young stems of ferns [probably Pteridium aquilinum (L) Kuhn] which are gathered by North and South Koreans living in Sweden.

\section{Berries and other fleshy fruits}

Fruits were not often eaten, although cowberries and cloudberries played a not unimportant role as food for the rural poor in the northern part of the country $[47,56]$ It was also possible to preserve them without sugar. Wild apple (Malus sylvestris Mill.) and wild pears (Pyrus communis L.) were used by the peasantry in Gotland and southern Sweden in the 18th century. The apples were used in soup, and sometimes regarded as food for poor people. Other fleshy fruits gathered were Sambucus nigra L., Prunus avium L., Prunus padus L., Cratageus sp., Ribes nigrum L., Ribes spicatum E. Robson, and Sorbus intermedia (Ehrh.) Pers. Fruits were dried and used as additives in pancakes or in bread, or eaten salted $[3,28,34,56]$. The traditional use of the sour fruits of sea-buckthorn, Hippophä rhamnoides L., was restricted to fishermen in the north part of the Bothnian Bay. They used them for sauce eaten together with fish $[3,28]$.

Naturalised Ribes uva-crispa L. berries were harvested by young people and sold in the cities, but the peasants also produced jam of it as was observed in Värmland in the mid19th century. Most people seem to have rejected the berries of Vaccinium uliginosum L., believing they were toxic, but in some areas in northern parts of Sweden they were actually eaten, not only by children but also adults. Juniper pseudofruits (Juniperus communis L.) were used by the peasantry for producing sweet syrup in western Sweden in the 18th and 19th century $[3,56]$.

The Saami gathered berries of Empetrum hermaphroditum (Hagerup) as food. It has been rarely used among the peasantry in the northern part of the country [13,28]. Rubus chamaemorus L. and Vaccinium vitis-idaeus L. were 
traditionally gathered and could be kept preserved especially in the north. The Finns in the central part of Sweden utilised large quantities of $V$. vitis-idaea berries in gruel, called "hillo" $[3,56]$. Fresh bilberries (Vaccinium myrtillus), in some areas completely despised as food, were sometimes elsewhere eaten with milk or cream, otherwise they were mostly eaten on the spot by children. The same is true for Rubus idaeus. With industrialisation and greater access to sugar some of these fruits became popular and are nowadays considered a must in Swedish food culture $[3,36,56]$.

\section{Grains, seeds, and nuts}

Hazelnuts (Corylus avellana) were widely gathered in the southern and middle part of Sweden. Servants at manors and large farms even had free days in the summer in order to gather nuts for their own consumption (especially for Christmas). Hazelnuts were also sold on the market, and even exported in large quantities [47,49]. From Gotland and Öland we have reports from the 18th and 19th century respectively that poor people harvested large amounts of high quality nuts from the winter nests of field mice, Apodemus flavicollis (Melchior) [57]. Also beechnuts Fagus sylvatica L. were gathered and used in flour, especially during times of crop failure. They were used as additives in bread $[3,56]$.

Seeds of Chenopodium album L. were widely gathered, dried, grained and mixed in flour for baking bread during crop-failures in northern Sweden [37,56]. However, grains of Glyceria fluitans (L.) R. Br. seem to have been gathered only very locally in Skillinge, Scania, in the mid-18th century. Linnaeus observed in Dalecarlia in 1734 that the locals used the grains of Avena fatua L. for flour [3,56].

\section{Bark, buds and other edible plants}

Traces of bark of Pinus sylvestris L. have been found in prehistoric breads from archaeological sites [58]. The innermost layer of $P$. sylvestris bark was commonly used to make bread among the peasantry in the northern Sweden still in the 18th century, but in the 19th century it was used mostly as flour substitute at times of famine. Bread mixed with bark flour was abandoned after the famine years 1867-1868. The energy content of bark flour is $82 \mathrm{kcal}$ per $100 \mathrm{~g}$. [56,59]. Due to the increasing economic importance of timber, the authorities were eager to replace the bark with other substances, such as lichens and mushrooms. The propaganda efforts increased in connection with crop failures. However, lichens and mushrooms were seen as cattle fodder and therefore generally rejected by the peasantry. The Saami have also been harvesting bark from pine trees. The inner bark was prepared by wrapping it in birch bark and put in the heat of a fire. The bark prepared in that way was sweet and eagerly eaten by the Saami. This kind of harvesting pine bark has been documented from late medieval times until the 19th century in Sweden [60].

The bark of Fagus sylvatica L. and Ulmus glabra L. were also used in southern Sweden as famine food in the early 19th century. In Småland the peasantry also used bark from Tilia cordata. Some sources also mention that the bark of Betula sp., and Picea abies (L.) H. Karst. was used for baking bread in times of famine [56].

\section{Spices, flavourings and preservatives}

Spices were grown in the villages and gardens of the manors for medicine or using for seasoning food. However, several plants were also gathered in the wild, such as Artemisia vulgaris
L., Carum carvi L., Mentha arvensis L., Origanum vulgare L. and Thymus serpyllum L. Spruce resin was commonly eaten as a refreshing chewing gum during the long services in churches or when walking in the forests $[3,61]$. Also resin from Prunus cereus L. was eaten by peasant boys in eastern Sweden in early 19th century. Haploporus odorus (Sommerf.) Bondartsev \& Singer is a bracket mushroom found on goat willow trunks in the northern part of Sweden. The species was widely used in cabinets and chests for its pleasant scent. However, it was also used to flavour cheese and bread [3,36-38].

A special case in Swedish folk botany was the use of the leaves of Pinguicula vulgaris L. and Drosera sp. in order to curdle milk when making a kind of dairy product known as "thickened milk" "tätmjölk". Whether the enzymes on the slimy plant leaves really contributed to the process is a matter of some debate, but most probably it was just an old folk belief. Locally, in the provinces of Värmland and Lapland, and adjacent areas of Norway, black slugs (Arion ater L.) were used to curdle the same kind of thick milk [62].

Hard liquor (brännvin) has traditionally been flavoured with plants, including wild species, such as Achillea millefolium L., Carum carvi L., Galium odoratum L., Myrica gale L., Gymnadenia nigra (L.) Reichb., Peucedanum palustre (L.) Moench., Potentilla erecta (L.) Räusch., Primula veris L., Tanacetum vulgare L., Taraxacum sp., as well as various fruits, such as Fragaria vesca L., Prunus padus L., Ribes nigrum L. and Sorbus aucuparia L. Still very popular is to gather the buds of Hypericum perforatum L. and to make a red light bitter with them $[3,56]$.

When making beer the peasantry also used wild plants. Most common seems to have been Myrica gale, but also Achillea millifolium L., Filipendula ulmaria (L.) Maxim., Gentianella campestris L. (Börner), Hypericum perforatum L., Juniperus communis L. (pseudo-fruits), Primula veris L., Menyanthes trifoliata L., Rhinanthus serotinus (Schönh.) Oborny, and Rhododendron tomentosum Harmaja are mentioned in the sources $[3,36,63]$.

A special kind of spices is the fragrant plants used in pipe tobacco and snuff. Sometimes (especially for children and elderly people) the plants substituted the real tobacco. Additives and surrogates were Achillea millefolium L., Arctostaphylos uva-ursi L., Arnica montana L., Galium odoratum L., Solanum dulcamara L., Centaurea cyaneus L., Hypericum perforatum L., Menyanthes trifoliata L. and Prunus cereus L. Snuff could be flavoured with scraps of the algae Trentepohlia iolithus (L.) Wallroth or with the fragrant grass Anthoxanthum odoratum L. The roots of Angelica archangelica L. and Peucedanum palustre (L.) Moench. were chewed by the Saami as substitutes for tobacco $[3,13,20,34,36]$. The plants used as tobacco substitutes have been reviewed in Norway and the Faroes. It could be a nice subject for a review covering a larger part of Europe $[2,4]$.

\section{Beverages}

Birch (Betula pendula Roth., B. pubescens Ehrh.) sap has been gathered all over Sweden and was usually seen as a refreshing drink, but has also been used for gruel (made of birch sap and barley meal), in coffee and in some areas (e.g. Dalecarlia) made into ale by mixing with malt and yeast [64].

In the 18th and 19th century it was a widespread custom to make a beverage of the pseudo-fruits from Juniperus communis L. Also poor people could make this drink. Juniper pseudofruits were sometimes made into beer and also syrup. Making cordials, wine and liqueurs of wild fruits was practiced in the 
upper classes already in the 18th century (and probably earlier as well). Also shoots of Picea abies (L.) H. Karst were brewed into a beverage $[3,56,63]$.

Drinks made of berries of Vaccinium vitis-idaea L. were common among the peasantry in certain parts of Sweden (for instance the Finns in Central Sweden) already in the $18 \mathrm{~h}$ and 19 th century. It does not require any sugar and it was a way to save the berries for the winter. In some areas the peasants made a drink of Vaccinium oxycoccos L. berries [3,56].

Making liqueurs out of wild fruits (e.g. Prunus spinosa L.) seems to be a more recent habit and has been a kind of vogue. Others are commercially produced. On the other hand, seasoning hard liquor with wild fruits like Sorbus aucuparia L. or Fragaria vesca L. are old habits stemming from the upper classes. Recipes of wine made of for instance Vaccinium myrtillus exists, but has not become popular. There was a time in the 1970s when it was a kind of fashion to make wine of Taraxacum sp. flowers. It was actually illegal to make homemade wine of the flowers from 1978, but the law was changed in 1994. Nowadays very few people make dandelion wine [3].

Among the Saami a hot drink made of the bracket fungus Piptoporus betulinus (Bull. ex Fr.) P. Karst. seems to have been common before coffee was introduced in the 1860s. During World War II when there was a shortage of imported food stuff, there was a revival of using the birch bracket fungus for making a hot drink among the Saami. It is still made into a drink by Saami children in Norway. Herbal tea has been made using Matricaria recutita L. already in the 1830s (and it is still sometimes gathered in the fields for the same purpose). Also flowers of Trifolium pratense $\mathrm{L}$. have been used to make herbal tea [3].

Coffee surrogates are known already in the early 19th century, although coffee was still restricted to the upper classes. It was not until the mid-19th century coffee became widely accepted [65]. Coffee substitutes are mentioned in cookbooks and recipe booklets from the late 19th century and World War I. However, ethnographical data also mentions dried rhizomes of Taraxacum sp. and seeds of Iris pseudacoris L. Coffee substitutes made of rye and/or chicory were available through the trade during the war-times [3].

\section{Children's snacks}

Children have always eaten green plants as a kind of treat and change in a rather monotonous diet of cereals and dried fish or meat. Especially children tending cattle in the forests had to complement the small amount of food they were given by their masters with Oxalis acetosella L., Rumex acetosa L., Angelica sylvestris L., Cicerbita alpina (L.) Wallr. and green shoots from Norway spruce, Picea abies (L.) H. Karst. These were not just snacks, but real food keeping them healthy and helping them to get enough energy $[3,66]$.

Children were and to some extant are still gathering plants as snacks (Tab. 1). Popular sour plants were Oxalis acetosella L. and Rumex acetosa L., locally also Rumex acetosella L. Also the immature pea-like fruits of Vicia cracca L. were popular. The immature fruits of Capsella bursa-pastoris (L.) Medik. have been eaten in southern Sweden. Sucking nectar from the flowers of Primula veris L., Trifolium pratense $\mathrm{L}$. and various Lamiaceae species (Lamium, Galeopsis) were common. Seeds of Bistorta vivipara (L.) Gray were widely eaten by children. Capsules of the hairy cap moss, Polytrichum commune Hedw., were gathered and eaten by children during springtime, appreciated for their sweet taste. Eating Chrysomyxa woroninii
Tab. 1 Plants traditionally eaten by children in Sweden $[3,40,56,66]$.
Taxa

Oxalis acetosella

Rumex acetosella

Primula veris

Galeopsis speciosa

Lamium album

Trifolium pratense

Prunus padus

Cornus suecica

Ribes alpinum

Ribes spicatum

Ribes uva-crispi

Vaccinium myrtillus

Vaccinium oxycoccos

Vaccinium uliginosum

Fragaria vesca

Empetrum hemaphroditum

Rubus caesius

Rubus chamaemorus

Rubus idaeus

Rubus saxatilis

Vicia cracca

Bistorta vivipara

Capsella bursa-pastoris

Betula sp.

Picea abies

Prunus cereus

Equisetum arvense

Polypodium vulgare

Polytrichum commune

Chrysomyxa woroninii
Rumex acetosa
Plant part used

leaves
leaves
leaves
nectar
nectar
nectar
nectar
fruits
fruits
fruits
fruits
fruits
fruits
fruits
fruits
fruits
fruits
fruits
fruits
fruits
fruits
seeds
seeds
seeds
sap
resin
resin
nodules
rhizomes
capsules
fungus on spruce shoots

Tranz., found on spruce shoots, has been a common practice among children. However, in the 19th century the Saami still gathered and ate them during the wanderings in forest areas as refreshment. Fruits were used too, including Vaccinium oxycoccos L. Some fruits were only utilised on the spot by children, for instance Cornus suecica L. and Rubus saxatilis L. $[3,34,36,37,39,40,66]$.

\section{Discussion}

\section{Malnutrition and famine food}

During the famine years at the end of the 16th century the peasantry used the chaff of frozen grain, flax fruits, bark, hazel buds, nettles, leaves, hay, straw, nut shells and vetch. At the end of the 19th century they were still using bark, leaves and straw in order to alleviate hunger $[44,56]$. Although Sweden was hit by several famines also including the 19th century, harvest failures never caused starvation through the total elimination of food [52] (Fig. 1).

The authorities' efforts to change people's food patterns by accepting new food items such as lichens and mushrooms were never accepted by the populace. Cultural barriers, taste preferences and distrust of those in power are factors explaining why 


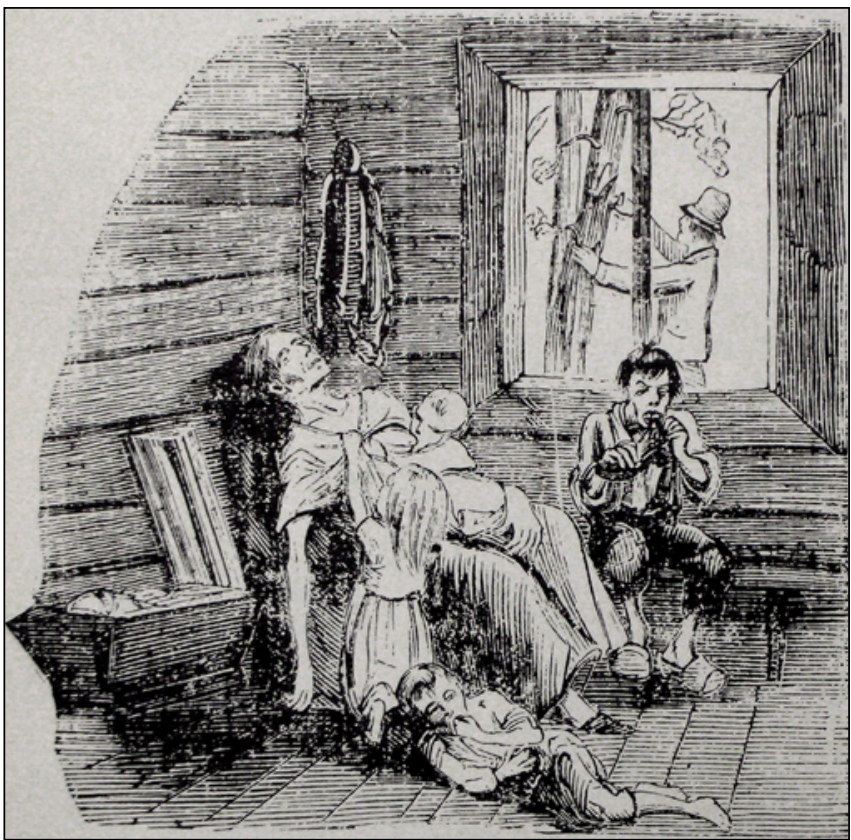

Fig. 1 Famine in Sweden in 1867. The boy is chewing on a shoe while his father harvests bark from a pine tree (From "Fäderneslandet", 1867).

the peasantry rejected these stuffs. They used food they were used to in other times as well, although they had to substitute flour with other plants. The inner bark of pine was still used during the food crisis in the 1860s. Straw, ears of grain and chaff were also popular, as were potatoes and root vegetables like swedes and turnips. Very few wild plants were actually used as emergency food (Tab. 2). If the peasants had been on the verge of starving to death, they most certainly would have eaten anything available (such as leather, rodents, dogs etc.) [67].

\section{Comparison with other Scandinavian countries}

Almost the same taxa as in Sweden were used in Norway. Some differences are due to the species available [2]. However, some plants, although common in Sweden, were not used. An interesting example is the West Nordic custom (Norway, Faroe Islands, Iceland and Shetland Islands) of eating the nutritious roots of Potentilla anserina L. which is not known from Sweden [68]. Although Sweden has a very long coastline, seaweed has not played any role as food or famine food in the same way as in Norway, Faroe Islands, Iceland and the British Isles. Seaweed has been used only as manure or for technical purposes [3]. It is only very recently that a small company in Grebbestad, Bohuslän, has started to make bread (crisp bread, baguette) of flour made of seaweed, Laminaria digitata (Hudson) J. W. Lamouroux.

\section{New trends in the 20th century and onwards}

Today especially wild fruits play an important role in Swedish food culture (Tab. 3). With increased access to cheap sugar in the early 20th century wild fruits (Vaccinium myrtillus, V. vitis-idaea, and Rubus chamaemorus) became very popular, especially among urban people. The fruits were used in the households for cordial, jam, gruel and desserts. $V$. vitis-idaea can be eaten with meat, fish, game, dumplings ("palt"), black pudding, porridge, ice-cream, cakes, biscuits, and desserts [69]. While writing this the present author had a
Tab. 2 Emergency bread additives reported in the 19th century $[7,56]$.

\begin{tabular}{ll}
\multicolumn{1}{c}{ Product } & \multicolumn{1}{c}{ Species } \\
\hline Underground parts & $\begin{array}{l}\text { Bistorta vivipara, Elytrigia repens, Calla } \\
\text { palustris, Menyanthes trifoliata, Solanum } \\
\text { tuberosum } \\
\text { Pinus sylvestris, Picea abies, Tilia cordata, Ulmus } \\
\text { Bark flour }\end{array}$ \\
Seeds & $\begin{array}{l}\text { Bistorta vivipara, Chenopodium album } \\
\text { Corylus avellana (buds, catkins), Picea abies } \\
\text { Buds, young shoots }\end{array}$ \\
Flowers, leaves and & $\begin{array}{l}\text { Salix caprea, Rumex acetosa, Trifolium pratense, } \\
\text { Tilia cordata, Epilobium angustifolium, Calluna } \\
\text { grass: }\end{array}$ \\
Fulgaris, Poaceae \\
Fruits & $\begin{array}{l}\text { Fagus sylvatica, Vaccinium vitis-idaea, Sorbus } \\
\text { intermedia } \\
\text { Chaff, straw, ears of grain, mash, horse manure, }\end{array}$ \\
Other substances & sawdust, soil, fish roe, bone meal
\end{tabular}

Tab. 3 Wild fruits and mushrooms picked for local consumption in Sweden 1990, 2000, 2005 [80].

\begin{tabular}{|c|c|c|c|}
\hline \multirow[b]{2}{*}{ Products } & \multicolumn{3}{|c|}{$\begin{array}{l}\text { Total quantity harvested/collected } \\
\text { (kilogram) }\end{array}$} \\
\hline & 1990 & 2000 & 2005 \\
\hline $\begin{array}{l}\text { Bilberry (Vaccinium } \\
\text { myrtillus L.) }\end{array}$ & 4754000 & 4800000 & 4300000 \\
\hline $\begin{array}{l}\text { Cowberry (Vaccinium vitis- } \\
\text { idaea L.) }\end{array}$ & 5950000 & 6000000 & 5850000 \\
\hline Rasberry (Rubus idaeaus L.) & 2250000 & 2200000 & 1700000 \\
\hline $\begin{array}{l}\text { Cloudberry (Rubus } \\
\text { chamaemorus L.) }\end{array}$ & 1900000 & 1900000 & 1325000 \\
\hline Mushrooms & 8640000 & 8500000 & 8910000 \\
\hline
\end{tabular}

1 litre of fruits $=0.5 \mathrm{~kg}$ fruits; 1 litre mushrooms $=0.6 \mathrm{~kg}$ mushrooms .

cowberry-cheesecake with his coffee at his break. Waffles with whipped cream and cloudberry jam are an appreciated treat among ordinary people and are often sold at festivals, fairs and other events all over the country. The furniture and product company IKEA serves Swedish meatballs with cream sauce and cowberry jam, instant rose hip soup and elderflower cordial in their department store restaurants and food stalls all over the world. Bilberries make everything from traditional jam to modern grappa [70]. Still only a fraction of the about 1000 million litres of fruits and 3600 million litres of mushrooms that are produced in Swedish forests every year are actually harvested [71].

Mushrooms were despised by the peasantry. However, mushrooms became accepted as food first among the Frenchinspired aristocracy in the 18th century and by the urban bourgeoisie in the late 19th century. Later also urban industrial workers became interested in picking mushrooms as a free food resource in the forests, especially after World War I. Fifty 
years ago working class people gathered only Cantharellus cibarius (Fr.) and occasionally Boletus edulis Bull. Nowadays more species are utilised in Swedish households, and especially the easily picked Cantharellus tubaeformis (Pers.) Fr. has become very popular since the 1970s, but also Cantharellus lutescens Fr., Craterellus cornucopioides (L.) Pers., Hydnum repandum L., Macrolepiota procera (Scop.) Singer, Suillus luteus (L.) Gray and occasionally also Lactarius deterrimus Gröger, just to mention a few, find their way into the basket. Many elderly people still only gather and use Cantharellus cibarius, being uncertain about the edibility of other taxa. Whether it is safe to eat Gyromita esculenta (Pers. ex Pers.) Fr. is disputed, but Morchella elata Fr. is gathered instead. Chinese immigrants, occasionally also others, pick Marasmius oreades (Bolton) Fr., in the urban lawns. Some cases of mushroom poisoning are reported every year [72]. A brochure available in many languages describing the 24 most common poisonous mushrooms in Sweden is published by Swedish Poison Information Centre (http://www.gic.se). Harvesting fruits and mushrooms in the forests is a popular pastime for many urban people (58 per cent of the population was picking fruits and mushrooms in 1997), but also a source of income for immigrants and especially foreign seasonal labour [47,73] (Fig. 2).

The only traditional green wild food plant that is regularly eaten in contemporary Sweden is Urtica dioica L. Occasionally some people gather Aegopodium podagraria L., once naturalised but nowadays considered an invasive weed, for food. Some wild species have become part of modern regional food culture. Allium scorodoprasum L. was traditionally used in coastal areas as a spring vegetable, especially in stews. On the island of Gotland, it has been harvested for centuries, and used as a remedy against spring fatigue. Today A. scorodoprasum $\mathrm{L}$. is an ingredient of a popular soup which is served as a local speciality all over Gotland [74]. Another recent example is jam made of Rubus caesius L. fruits, hardly eaten before but now a regional speciality also in Gotland. The jam is usually eaten with a local kind of pancake flavoured with saffron [75]. Products (jam, cordial) made from berries of Vaccinium oxycoccos L. and Empetrum sp. are also available. The real success, however, has been the fruits of Hippophaë rhamnoides L., which began to be very popular a couple of decades ago. Although most fruits are nowadays harvested from cultivated plants, some people actually gather them from wild plants along the Baltic coastline. Jam and juice of wild sea buckthorn fruits can actually be bought at Uppsala's weekly market [76].

Many herbs were used as spices (and medicine) in the peasant society, but during industrialisation most of them were forgotten by the working class people. Nowadays herbs are coming back into the households and Swedes use a lot of culinary herbs, although most of them are cultivated in gardens or bought in stores. Wild spice plants are not gathered anymore. General trends sometimes increase the interest for wild plants, such as making tea of Tilia cordata L. or homemade cordials from the flowers of Sambucus nigra L., Filipendula ulmaria (L.) Maxim. or Centaurea cyanus (L.) Hill, and making elderberry "capers" of unripe fruits.

Many wild food plants are today known through the many handbooks available in bookshops. Newspapers also have articles on the subject each summer. It is hard to determine how many people actually try using these recipes. Some consider wild plants as healthier than cultivated plants; others appreciate them for being a free resource. Alliaria petoliata (M. Bieb.)

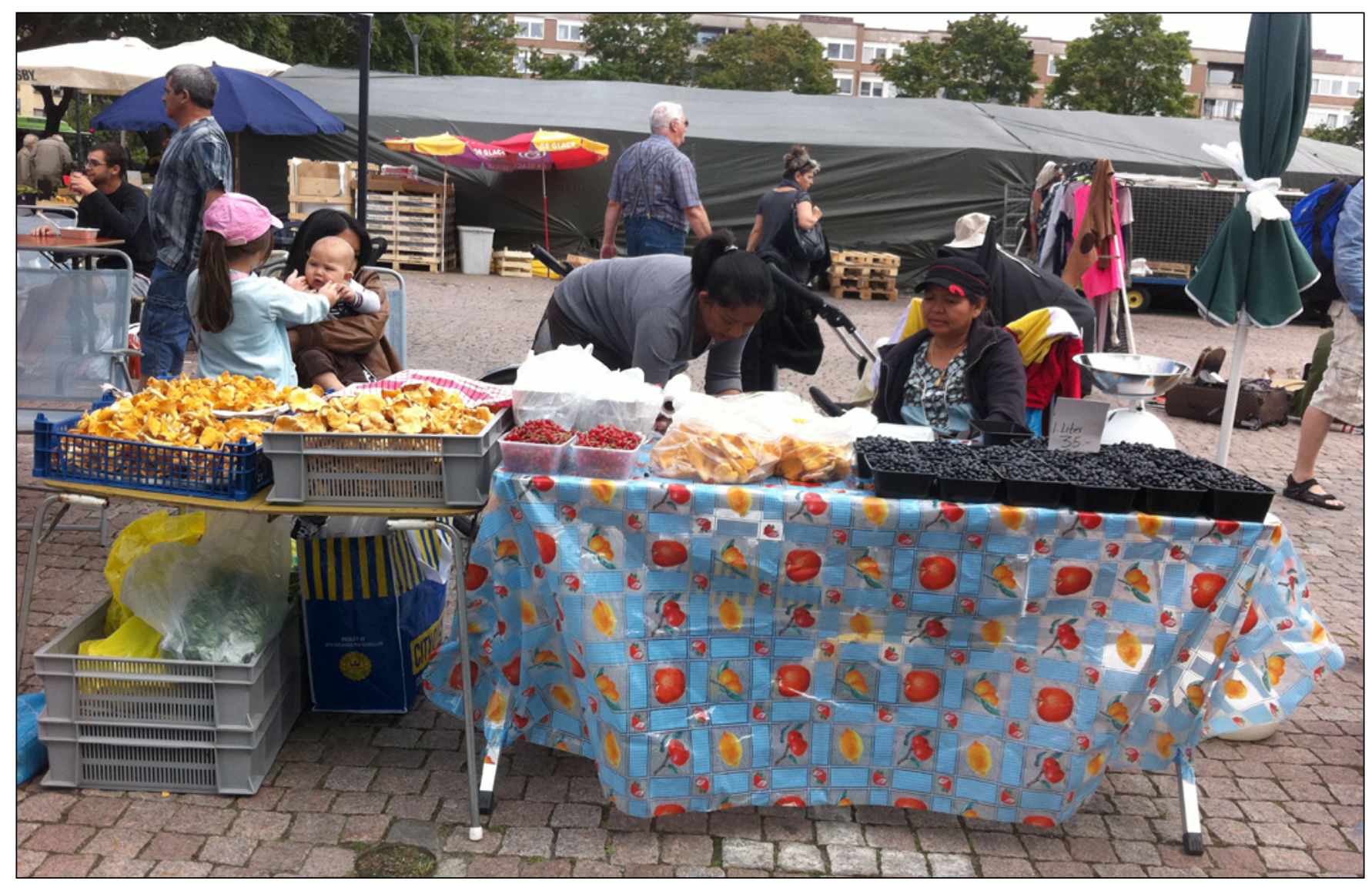

Fig. 2 Thai women selling chanterelles, Cantharellus cibarius (Fr.), and bilberries, Vaccinium myrtillus L., on a Saturday market in Uppsala in August 2012 (photograph by Navarana Ingvarsdóttir). 
Cavara \& Grande, Capsella bursa-pastoris (L.) Medik. and Lamium album L. are examples of plants mentioned in these modern recipes $[77,78]$. There are of course also specialists using and promoting wild plants as food, including individuals and small circles inspired by New Age ideologies or for other ideological and pseudo-scientific reasons (homeopathy). However, generally speaking their sources are not from the old folk-knowledge but from old and modern propaganda books (and nowadays also through the Internet).

\section{Conclusions}

Apart from aromatic fruits and some mushrooms, other wild plants are very little used today, despite propaganda efforts to create an interest in them. Sweden in the past must be regarded as a herbophobous society, according to the ethnobotanist Łuczaj's categorization [79]. Wild green plants have been and still are of very limited interest for most people. However, lettuce and other cultivated greens are easily available in the grocery stores throughout the year, and so are herbs. Cultivated fruits and vegetables are always available. Modern Swedes now eat a lot of vegetables in their daily meals. It is part of contemporary food culture.

Wild fruits and mushrooms have increased in importance in recent years and are very much used, not only in households but also in restaurants and food industry [80] (Tab. 3). Cowberry Vaccinium vitis-idaea L. jam can for instance be used with almost all kinds of dishes. The right of public access in the countryside, which entitles people to pick fruits, to gather mushrooms and to pursue various outdoor activities, is important for our understanding of the landscape and its products. However, it is also a source of income for many people, previously for people in the countryside in the 20th century, nowadays for immigrants (especially Thai women) and foreign seasonal workers (Tab. 4). Now and then there is also an interest in green plants. Survival courses are given not only by the military, but today also by high schools, educational TV-programs and instructions given in evening classes, with information on how to use wild plants as food. People lost in the forests know how to use the available resources. Many people are used to outdoor life. An angler, who in the summer of 2012 was lost for almost two weeks in the forests of Jämtland, survived by eating spruce shoots and unripe fruits of Rubus chamaemorus L. before he was found again unharmed by his experiences.

Tab. 4 Food products of wild taxa available at the weekly market on Fyris torg, Uppsala, in 18 August 2012.

\begin{tabular}{llll}
\hline \multicolumn{1}{c}{ Species } & & & Frozen \\
& Cordial & Jam & leaves \\
\hline Bilberry (Vaccinium myrtillus L.) fruits & $\times$ & $\times$ & \\
Cowberry (Vaccinium vitis-idaea L.) fruits & $\times$ & $\times$ & \\
Wild raspberry (Rubus idaeaus L.) fruits & & $\times$ & \\
Cloudberry (Rubus chamaemorus L.) fruits & & $\times$ & \\
Wild strawberry (Fragaria vesca L.) fruits & $\times$ & & \\
Blackthorn (Prunus spinosa L.) fruits & $\times$ & & \\
Elder (Sambucus nigra L.) flowers & $\times$ & & \\
Nettle (Urtica dioica L.) shoots/leaves & & \\
\end{tabular}

\section{Acknowledgments}

The author owes his sincere gratitude to Professor tukasz Łuczaj (Poland), Professor Marie Clark Nelson (Sweden) and Mr Nicholas Redman (U. K.) for comments on the first draft of this article and for help of various kinds.

\section{References}

1. Brøndegaard VJ. Folk og flora: Dansk etnobotanik. København: Rosenkilde \& Bagger; 1978. (vol 1-4).

2. Høeg OA. Planter og tradisjon: floraen i levende tale og tradisjon i Norge 1925-1973. Oslo: Universitetsforlaget; 1974.

3. Svanberg I. Folklig botanik. Stockholm: Dialogos; 2011.

4. Svanberg I. The use of wild plants in the Faroe Islands, 1590-1990: a contribution to Scandinavian ethnobotany. Svenska Linnésällskapets Årsskrift. 1998;1996-1997:81-130.

5. Manninen I. Überreste der Sammlerstufe und die Notnahrung aus dem Pflanzenreich bei den nordeurasischen, vorzugsweise den finnischen Völkern. Eurasia Septentrionalis Antiqua. 1931;6:30-48.

6. Guðmundsson G. Gathering and processing of lyme-grass (Elymus arenarius L.) in Iceland: an ethnohistorical account. Veget Hist Archaeobot. 1996;5:13-23.

7. Nelson MC, Svanberg I. Lichens as food: historical perspectives on food propaganda. Svenska Linnésällskapets Årsskrift. 1987;1986-1987:7-51.

8. Svanberg I, Nelson MC. Bone meal porridge, lichen soup, or mushroom bread: acceptance or rejection of food propaganda 1867-1868. In: Häkkinen AJ, editor. Just a sack of potatoes? Crisis experiences in past and present societies. Helsinki: Societas Historica Finlandiae; 1992. p. 119-147.

9. Egardt B. Svenskarna och svampmaten. Rig. 1954;37:33-44.

10. Klintberg B. Kuttrasju: folkloristiska och kulturhistoriska essäer. Stockholm: Norstedt; 1998.

11. Fjellström P. Angelica archangelica in the diet of the Lapps and the Nordic peoples. In: Furumark A, Lagercrantz S, Nesheim A, Widegren G, editors. Lapponica: essays presented to Israel Ruong 26.5.1963. Uppsala: Uppsala University; 1964. p. 99-115. (Studia Ethnographica Upsaliensia; vol 21).

12. Aronsson KÅ. Användning av ängssyra (Rumex acetosa) bland samerna. In: Svanberg I, Tunón H, editors. Samisk etnobiologi: människor, djur och växter i norr. Nora: Nya doxa; 2000. p. 253-258.

13. Svanberg I. Samisk etnobiologi. In: Svanberg I, Tunón H, editors. Samisk etnobiologi: människor, djur och växter i norr. Nora: Nya doxa; 2000. p. 13-58.

14. Svanberg I. Ethnobotany. In: Kulonen UM, Seurujärvi-Kari I, Pulkkinen R, editors. The Saami: a cultural encyclopedia. Helsinki: Suomalaisen Kirjallisuuden Seura; 2005. p. 104-105.

15. Svanberg I. The Sami use of Lactuca alpina as a food plant. Svenska Linnésällskapets Årsskrift. 2002;2000-2001:77-84.

16. Tillhagen $\mathrm{CH}$. Food and drink among the Swedish Kalderaša Gypsies. Journal of the Gypsy Lore Society, 3rd Ser. 1957;34:25-52.

17. Svanberg I. Fjällsyra, Oxyria digyna. In: Tunón H, Pettersson B, Iwarsson M, editors. Människan och floran: etnobiologi i Sverige. Stockholm: Wahlström \& Widstrand; 2005. p. 277. (vol 2).

18. Pettersson B, Svanberg I. Hassel, Corylus avellana. In: Tunón H, Pettersson B, Iwarsson M, editors. Människan och floran: etnobiologi i Sverige. Stockholm: Wahlström \& Widstrand; 2005. p. 158-160. (vol 2).

19. Svanberg I. Svinmålla, Chenopodium album. In: Tunón H, Pettersson B, Iwarsson M, editors. Människan och floran: etnobiologi i Sverige. Stockholm: Wahlström \& Widstrand; 2005. p. 197. (vol 2).

20. Svanberg I. “The Lapps chew this root a lot”: milk parsley (Peucedanum palustre) in Sami plant knowledge. In: Fransson U, Svendin M, Bergerbrant S, Androschuck F, editors. Cultural interaction between east and west. Archaeology, artefacts and human contacts in northern Europe. 
Stockholm: Stockholm University; 2007. p. 328-330.

21. Svanberg I. Garden angelica (Angelica archangelica). In: Cumo CM, editor. Encyclopedia of cultivated plants. Santa Barbara CA: ABC-CLIO. In press.

22. Svanberg I. Caraway (Carum carvi). In: Cumo CM, editor. Encyclopedia of cultivated plants. Santa Barbara CA: ABC-CLIO. In press.

23. Svanberg I. Tansy (Tanacetum vulgare). In: Cumo CM, editor. Encyclopedia of cultivated plants. Santa Barbara CA: ABC-CLIO. In press.

24. Erixon S. Surviving primitive gathering in the Nordic countries. Folk-Liv. 1951;14-15:95-102.

25. Sporrong U. The Swedish landscape: the regional identity of historical Sweden. In: Jones M, Olwig K, editors. Nordic landscapes: region and belonging on the Nordic edge of Europe. Minneapolis MN: University of Minnesota Press; 2008. p. 141-156.

26. Svanberg I. Cultural and language pluralism in contemporary Nordic countries. In: Fossum Grønn J, editor. Nordic voices: literature from the Nordic countries. Oslo: Nordbok; 2005. p. 8-17.

27. Balick MJ, Cox PA. Plants, people, and culture: the science of ethnobotany. New York NY: Scientific American Library; 1996.

28. Linnaeus C. Flora Lapponica. Amsterdam: Salomon Schouten; 1737.

29. Svanberg I. Etnobiologen Linné. In: Jacobsson R, editor. Så varför reser Linné? Perspektiv på Iter Lapponicum 1732. Umeå: Carlsson; 2005. p. $135-162$.

30. Svanberg I. The use of lichens for dyeing candles: ethnobotanical documentation of a local Swedish practice? Svenska Landsmål och Svenskt Folkliv. 1998;324:133-139.

31. Svanberg I. Fabulat, plagiat och spökuppgifter: att använda berättande källor inom etnobiologi. In: Nycklar till kunskap: om människans bruk av naturen. Stockholm: Kungliga Skogs- och Lantbruksakademien; 2010. p. 123-136.

32. Svanberg I. Linneaner: Carl von Linnés lärjungar i Sverige. Stockholm: Wahlström \& Widstrand; 2006.

33. Svanberg I. Källor till folklig kunskap. In: Tunón H, Pettersson B, Iwarsson M, editors. Människan och floran: etnobiologi i Sverige. Stockholm: Wahlström \& Widstrand; 2005. p. 23-34. (vol 2).

34. Bergfors G. Från självhushållets dagar i ett ångermanländskt jordbrukarhem. Ångermanland. 1947;4:59-76.

35. Fridner G. Folkliga växtnamn i Västerbotten. Umeå: Språk- och folkminnesinstitutet; 1999.

36. Svanberg I. Folkbotaniska uppgifter från Borgsjö socken i Medelpad: Gullik Gullikssons anteckningar från 1955. Uppsala: Maral Production; 2004.

37. Modin E. Växtnamn samt folkliga bruk och föreställningar rörande växter i Härjedalen. In: Festskrift til H. F. Feilberg fra nordiske sprog- og folkemindeforskere på 80 års dagen den 6. August 1911. Kristiania: Bymaalslaget; 1911. p. 697-737.

38. Landsmålsarkivets frågelista. 19, Nödbröd ock nödfoder. Svenska Landsmål och Svenskt Folkliv. 1929;22:213-226.

39. Johansson L. Växtnamn m.m. Manuscript collection (cat. No. ULMA 19 857). Uppsala: Swedish Institute for Dialects and Folklore; 1949.

40. Bergvall F. Edseles folkliga flora: växtnamn (latin, dialekt, riksspråk jämte uppgifter om växternas användning. Manuscript collection (cat. No. ULMA 28 641). Uppsala: Swedish Institute for Dialects and Folklore; 1972.

41. Drake G. Linnés försök till inhemsk teodling. Svenska Linnésällskapets Årsskrift. 1927;10:68-83.

42. Räsänen L. Of all foods bread is the most noble: Carl von Linné (Carl Linneaus) on bread. Scand J Food Nutr. 2007;51:91-99.

43. Linnaeus C. Archiaterns och riddarens af Kongl. Nordstjerne Orden Carl Linnæi berättelse om the inhemska wäxter, som i brist af säd kunna anwändas til bröd- och matberedning. Stockholm: Kongl. Tryckeriet; 1757.

44. Svanberg I. Fattigmanskost. In: Broberg G, Lindell G, editors. Till livs med Linné: om mat hälsa och levnadskonst. Stockholm: Atlantis; 2007. p. 185-195.

45. Lundström E. Ätliga vilda växter: en dyrtidsbok. Stockholm: Norstedt; 1918.
46. Holmboe J. Gratis mat av vilda växter. Stockholm: Albert Bonnier; 1942.

47. Pettersson B. Nötter, bär och svamp. In: Pettersson B, Svanberg I, Tunón H, editors. Människan och naturen: etnobiologi i Sverige. Stockholm: Wahlström \& Widstrand; 2001. p. 147-154. (vol 1).

48. Nordenstreng E. 72 sätt att tillaga de vitaminrika rönnbären jämte inledande kapitel om rönnbär i folktro och forskning. Stockholm: Albert Bonnier; 1934.

49. Kardell L. Utmarkens bär och svampar samt inmarkens nötter. In: Lindwall B, editor. Tjära, barkbröd och vildhonung. Stockholm: Nordiska museet; 1996. p. 138-155.

50. Ekvall U. Gotländska växtnamn: tradition och förnyelse i ett lokalt växtnamnskick. Stockholm: Almqvist \& Wiksell International; 1990.

51. Turner NJ, Łuczaj ŁJ, Migliorini P, Pieroni A, Dreon AL, Sacchetti LE, et al. Edible and tended wild plants, traditional ecological knowledge and agroecology. Cr Rev Plant Sci. 2011;30(1-2):198-225. http://dx.doi.org/ 10.1080/07352689.2011.554492

52. Nelson MC. Bitter bread: the famine in Norrbotten 1867-1868. Uppsala: Acta Universitatis Upsaliensis; 1988. (Studia Historica Upsaliensia; vol 153).

53. Høeg OA. Har De spist blåveis- eller hvitveisblomster om våren? Blyttia. 1950;8:126-128.

54. Svanberg I. Field horsetail (Equisetum arvense) as a food plant. Fróðskaparrit: Annales Societatis Scientiarum Færoensis. 1997;45:45-55.

55. Edlund LE, Svanberg I. Rallarros, Epilobium angustiforlium. In: Tunón H, Pettersson B, Iwarsson M, editors. Människan och floran: etnobiologi i Sverige. Stockholm: Wahlström \& Widstrand; 2005. p. 193-194. (vol 2).

56. Keyland N. Svensk allmogekost. Stockholm: Svenska Teknologförening; 1919. ( vol 1).

57. Ståhlberg S, Svanberg I. Gathering food from rodent nests in Siberia. J Ethnobiol. 2010;30:184-202. http://dx.doi.org/10.2993/0278-0771-30.2.184

58. Hansson AM. Pre- and protohistoric bread in Sweden: a definition and a review. Civilisations. 2002;49:183-190.

59. Niklasson M. Bark som människoföda ur agrart och samiskt perspektiv. In: Lindwall B, editor. Tjära, barkbröd och vildhonung. Stockholm: Nordiska Museet; 1996. p. 107-125.

60. Zackrisson O, Östlund L, Korhonen O, Bergman I. The ancient use of Pinus sylvestris L. (Scots pine) inner bark by Sami people in northern Sweden, related to cultural and ecological factors. Veg Hist Archaeobot. 2000;9:99-109. http://dx.doi.org/10.1007/BF01300060

61. Vilkuna K. Das Kauharz, ein uraltes Genussmittel. In: Furumark A, Lagercrantz S, Nesheim A, Widegren G, editors. Lapponica: essays presented to Israel Ruong 26.5.1963. Uppsala: Uppsala University; 1964. p. 295-303. (Studia Ethnographica Upsaliensia; vol 21).

62. Ränk G. Vilken roll har tätörten spelat i mjölkhushållningen? Folktro kontra vetande. Folk-Liv. 1961;24-25:65-75.

63. Hofsten N. Pors och andra humleersättningar och ölkryddor i äldre tider. Uppsala: Lundequistska; 1960. (Acta Academiae Regiae Gustavi Adolphi; vol 36).

64. Berg G. Att tappa björklake. Gastronomisk kalender. 1968:35-57.

65. Nelson MC, Svanberg I. Coffee in Sweden: a question of morality, health, and economy. Food Foodways. 1993;5:239-254. http://dx.doi.org/10.108 0/07409710.1993.9962006

66. Bergfors G. Vad roade sig barnen med när farfars far var liten? Fjällsjö Krönika. 1966;17:33-54.

67. Scrimshaw NS. The phenomenon of famine. Annu Rev Nutr. 1987;7:1-22. http://dx.doi.org/10.1146/annurev.nu.07.070187.000245

68. Holmboe J. Mura (Potentilla anserina L.) og dens bruk som matnyttnig plante i ældre og nyere tid. Svensk Botanisk Tidskrift. 1928;22:160-168.

69. Bringéus NA. The red gold of the forest. In: Lysaght P, editor. Food from nature, attitudes, strategies and culinary practices. Uppsala: Academiae Regiae Gustavi Adolphi; 2000. p. 225-239. (Acta Academiae Regiae Gustavi Adolphi; vol 71).

70. Rattfelt A, Lunøe Pihl S. Blåbär: minnen, mat och smak. Stockholm: 
Balkong; 2008.

71. Kardell L. Forest berries and mushrooms: an endangered resource? Ambio. 1980;9:241-247.

72. Irestedt B, Persson H, Sjöberg G. Förgiftningstillbud bland barn är vanliga men oftast inte allvarliga. Läkartidningen. 2004;101:2256-2260.

73. Lindhagen A, Hörnsten L. Forest recreation in 1977 and 1997 in Sweden: changes in public preferences and behaviour. Forestry. 2000;73:143-153. http://dx.doi.org/10.1093/forestry/73.2.143

74. Genrup K. Skogslök, Allium scorodoprasum. In: Tunón H, Pettersson B, Iwarsson M, editors. Människan och floran: etnobiologi i Sverige. Stockholm: Wahlström \& Widstrand; 2005. p. 271. (vol 2).
75. Svanberg I. Blåhallon, Rubus caesius. In: Tunón H, Pettersson B, Iwarsson M, editors. Människan och floran: etnobiologi i Sverige. Stockholm: Wahlström \& Widstrand; 2005. p. 259. (vol 2).

76. Svanberg I. Knallgul saft på Fyris torg. Biodiverse. 1998;3(2):8-9.

77. Ingmansson I. Kan man äta sånt? Stockholm: Prisma; 1996.

78. Källman S. Vilda växter som mat och medicin. Västerås: Icaförlaget; 1997.

79. Łuczaj ŁJ. Changes in the utilization of wild green vegetables in Poland since the 19th century: a comparison of four ethnobotanical surveys. J Ethnopharmacol. 2010;128(2):395-404. http://dx.doi.org/10.1016/j. jep.2010.01.038

80. Country report: Sweden. Rome: FAO; 2005. 